\title{
CARDIOVASCULAR COLLAPSE FOLLOWING SUCCINYLCHOLINE IN A PARAPLEGIC PATIENT
}

\author{
By J. C. Snow, ${ }^{1}$ M.D., B. J. Kripke, M.D., G. P. Sessions, M.D. and \\ A. J. FINCK, M.D. \\ University Hospital, Boston, DeKalb General Hospital, Decatur, Georgia, and \\ Boston University School of Medicine, Boston, Massachusetts 02I 8
}

\section{INTRODUCTION}

SEVERAL reports have been presented that have discussed cardiovascular collapse following the intravenous infusion of succinylcholine in patients with burns, massive trauma, tetanus, spinal cord injury, brain injury, upper or lower motor neuron disease, and uraemia with increased serum potassium.

The purpose of this article is to report a spinal cord injured patient who developed cardiac arrest following administration of succinylcholine, possibly due to succinylcholine-induced hyperkalaemia. The anaesthesia management during the course of subsequent surgical procedure proved to be uneventful.

\section{CASE REPORT}

On 7 December 1971, a 20-year-old white man was admitted to the hospital after he fell 50 feet from a scaffold to the ground. He was reported to have been in good health until this accident. His legs and outstretched hands absorbed the major impact. No loss of consciousness was reported at any time. Neurologic examination revealed absent function of muscle groups in the distribution distal to $\mathrm{L}_{4}$, including the sacral segments. There were contractions of both quadriceps muscles in the adductors of the legs. The legs were held in flexion with no evidence of function in his hip abductors, extensors, knee flexors or anything below his knee. He had intact sensation over the entire thigh and medial calf. He had no apparent abdominal or cremasteric reflexes, no knee or ankle jerks, no Babinski responses, and no sacral sparing. All of these findings were consistent with paraplegia below an L4 level. Roentgenographic examination indicated a compression fracture of $\mathrm{L}_{4}$ and $\mathrm{L}_{5}$. Further examination showed multiple fractures of his forearms and legs. The left chest was the site of haemothorax from which $1200 \mathrm{ml}$. of blood were evacuated.

On the day of admission, the patient had closed reduction of forearm fractures under general endotracheal anaesthesia. He received succinylcholine $60 \mathrm{mg}$. for intubation. Drugs used during the anaesthesia management included thiopental, nitrous oxide, morphine and tubocurarine. On the 8th hospital day, aortography revealed a traumatic aneurysm of the proximal descending thoracic aorta. On the 9th day the patient underwent surgical repair of the aneurysm. A dacron prosthesis was used. Endotracheal intubation and maintenance of anaesthesia were managed with thiopental, nitrous oxide and halothane. The patient did not receive succinylcholine for intubation. On the It th post-injury day, all extremity casts were changed. The next day he underwent open reduction and internal fixation of left tarsal metatarsal dislocation. No anaesthesia was given.

${ }^{1}$ Boston University School of Medicine, Dept. of Anesthesiology, 750 Harrison Avenue, Boston, Mass. O2I I 8.

$$
\text { I I } / 3-P
$$


On the 22nd hospital day the patient was thought stable enough to be transferred to DeKalb General Hospital. At this time he was able to extend both knees and lift each leg from the bed. His vital signs were stable and he was on oral intake. A bladder catheter was in place. A voiding cystogram revealed no bladder abnormalities or evidence of reflex. Anal sphincter tone was poor. Gluteal bulk was decreased, associated with flaccidity of the buttocks.

On 3 January 1972 ( 27 days post-injury), the patient was scheduled for an open reduction of the tibia and manipulation of both wrists. Premedication consisted of $50 \mathrm{mg}$. meperidine, $25 \mathrm{mg}$. promethazine and $0.4 \mathrm{mg}$. atropine. Blood pressure and pulse were I $50 / 90$ and I 30 respectively. For induction of anaesthesia he received I $75 \mathrm{mg}$. thiopental in divided doses. Nitrous oxide ( 2 litres) and oxygen ( 2 litres) with I per cent. halothane was started. While anaesthesia was being established following the thiopental induction, the casts were removed from the arms and manipulations of the wrists were undertaken. Three minutes later a 0.2 per cent. succinylcholine drip was started, the halothane vaporiser was shut off and hyperventilation commenced. Following a dose of approximately $75 \mathrm{mg}$. succinylcholine, the trachea was easily intubated. Six minutes later blood pressure was IIO/80, and then cardiac standstill occurred. The arrest was diagnosed by means of a taped-on precordial stethoscope.

The patient was hyperventilated with oxygen. Closed-chest massage immediately produced good femoral pulses. An ECG was attached; $200 \mathrm{mEq}$./1. of sodium bicarbonate and I ml. of I : I000 epinephrine was given. Once the patient was defibrillated, he quickly returned to preanaesthetic levels of blood pressure and pulse. Serum electrolytes $\mathrm{I} \frac{1}{2}$ hours after the induction of anaesthesia were $\mathrm{Na} I 38 \mathrm{mEq} . / 1 ., \mathrm{K} 3 \cdot 3, \mathrm{Cl} 95, \mathrm{CO}_{2} 27 \cdot 3$. Two days later, these values were $\mathrm{Na}_{13} 6, \mathrm{~K} 4 \cdot 2, \mathrm{Cl} 102, \mathrm{CO}_{2} 24 \cdot 6$. No further neurologic impairment was detected. The open reduction of the tibia was not undertaken. The patient had no subsequent anaesthesia in this hospital. Examination on I 7 January 1972, showed a bulbocavernous reflex with anal sphincter tone present. Genito-urinary examination showed him able to void with a great deal of difficulty voluntarily, but no residuals were done.

On 27 February the patient was discharged home. At home he had poor bladder control in that he was probably emptying over dribbling from a significant residual bladder volume. Bowel was managed by enemata, but there were frequent episodes of bowel incontinence, particularly while taking a tub bath. On 4 March there developed systemic evidence of urinary tract infection and he was admitted to the hospital. The signs and symptoms cleared after use of antibiotics. The indwelling catheter which was inserted on admission was removed after three days. He has been able to achieve penile erection.

On 20 March 1972, the patient was admitted to the University Hospital in Boston, with an impairment of $\mathrm{L}_{4}$ functional level paraplegia. On admission, the results of the blood and urine chemistry analyses were within normal limits. Myelographic study revealed a complete block at the inferior margin of the L3-4. Urine culture (patient on sulfisoxazole) produced less than I0,000 colonies per millilitre. Post-voiding residual on 23 March was $450 \mathrm{ml}$. Rectal sphincter tone was loose, and there were feaces in ampulla without tenderness. There was no spasticity or rigidity in either leg, and he appeared to have incontinence of both bowel and bladder. Muscle atrophy was present in both legs. He appeared to have a cauda equina syndrome with partial weakness of his quadriceps, no hip abduct, placing the lesion at $\mathrm{L}_{4}$. He did not have count of bowel or bladder, and no ankle jerks. On I3 April (I28th post-injury day), the patient underwent decompressive laminectomy of $\mathrm{L}_{3}, \mathrm{~L}_{4}$ and $\mathrm{L}_{5}$, with the hope of preserving some function below the level $\mathrm{L}_{3}-4$. He was found to have a linear fracture of the left lamina of $\mathrm{L}_{4}$ which penetrated the dura and transected a number of roots in the left gutter. The remaining roots were severely matted together.

Anaesthesia Management. Premedication consisted of pentobarbital, morphine and atropine. In the operating room, a blood pressure cuff was placed on the arm, the 
electrodes of the electrocardioscope with a heart rate meter and electrocardiogram were attached on the chest and extremities, and droperidol $5 \mathrm{mg}$. $(2 \mathrm{ml}$.) was administered intravenously. An intravenous drip of lactated Ringer's solution $1000 \mathrm{ml}$. was started in the dorsum of the left hand and a nerve stimulator was attached on the same arm. An intravenous 18-gauge plastic catheter was inserted in the antecubital fossa of the right arm for withdrawal of blood for serial blood analysis.

At ro.10 a.m., thiopental $75 \mathrm{mg}$. and tubocurarine $15 \mathrm{mg}$. were injected. At 10.15 thiopental $50 \mathrm{mg}$., tubocurarine $15 \mathrm{mg}$. and gallamine $40 \mathrm{mg}$. were given. The patient was hyperoxygenated with a face mask and oxygen 6 litres/minute. At 10.20 gallamine $80 \mathrm{mg}$. was administered. At IO.2I intubation was performed, and the patient's position changed to prone at 10.32. Surgery started at 10.50. Anaesthesia under control respiration was maintained with nitrous oxide (4 litres) and oxygen (2 litres). Additional drugs used during the maintenance of anaesthesia were fentanyl $0.15 \mathrm{mg}$. $(3 \mathrm{ml}$.) and tubocurarine $6 \mathrm{mg}$. Both anaesthesia and surgery were uneventful. Surgery was completed at I.I 5 p.m. Venous blood analysis at IO.IO, IO.I4, IO.2I and IO.25 for serum potassium and I2-lead electrocardiographic serial tracings taken during this period revealed no evidence of hyperkalaemia.

Post-operatively. There was temperature elevation to $100^{\circ} \mathrm{F}$. during the first four post-operative days. This was less of a problem than the post-operative depression, anorexia, nausea and emesis. No organic basis could be detected for these symptoms. The consultant psychiatrist noted that the patient was behaving in a regressed manner. He was demanding and angry, and behaving in a hostile and aggressive manner to the staff. Psychiatric complications were treated with Thorazine without improvement, and later on with Elavil on high dosages. While on his medication a good recovery was seen.

During early May, he continued to have a number of unresolved emotional conflicts which precluded his reaching his potential functioning within the limits of his neurologic impairment. He had continued to focus on his nervousness, and was convinced that if he could return home he would function well from a physical standpoint. On 23 May, stress films of the lumbo-sacral spine revealed instability of $\mathrm{L}_{4}$ on both $\mathrm{L}_{3}$ and $\mathrm{L}_{5}$.

By 8 June, it was noted that his emotional improvement continued to an almost remarkable extent. He was delighted with his progress in physical functioning and his self-esteem had increased considerably. The symptoms of depression, anorexia and sleep disturbance had cleared. On I3 June, the post-voiding residual volume was $175 \mathrm{ml}$. The Urecholine was increased to I $50 \mathrm{mg}$. daily with improvement. On 22 June, residual was over $100 \mathrm{ml}$. and on 27 June, the residual was $10 \mathrm{ml}$. Urine specimen submitted for culture on 12 and 16 June produced no growth.

Manual muscle testing on 7 June revealed good minus adductors bilaterally, normal minus left quadriceps, good plus right quadriceps, good minus hip flexors bilaterally, and trace knee flexors. All ankle and foot musculature graded zero (no evidence of contractility).

At the time of discharge on 28 June 1972, he was completely independent in self-care activities from a wheelchair and in addition with the short leg braces which he brought with him and which were attached to high top full to toe lacings, he was ambulatory with both axillary or forearm type cratches. This type of shoe was necessary for distal deformity particularly the forefoot equinus.

Bladder evacuation was aided by use of an external collecting device. Bowel was continent on a regimen of a glycerin suppository on alternate evenings and Colace $100 \mathrm{mg}$. three times daily. Discharge medications were: Hiprex, Colace, Valium, and Urecholine. Discharge diagnosis: $\mathrm{L}_{4}$ and $\mathrm{L}_{5}$ fractures with cauda equina injury, $\mathrm{L}_{4}$ functional level paraplegia, neurogenic bowel and bladder regulated, and multiple fractures forearms and legs. With recommendations that his urinary tract function must be observed, and at least monthly routine urinalysis and cultures should be done with intravenous pyelography in six months. In regards to back to work limitations, the decision was deferred. 
End of January 1973, he was hospitalised at DeKalb General Hospital for a cystoscopic examination and everything went smoothly. On 7 July the urologist examined the patient in the office and said that the patient is doing well and that he walked without braces or canes. No pyuria since his last admission to the hospital in January 1973. In addition, the urologist said that the patient was 'piddling' at whatever he wanted to do and the insurance company was still paying him.

\section{DISCUSSION}

Succinylcholine produced a small but significant rise in serum potassium in a series of patients undergoing dental extraction under thiopental anaesthesia (Paton, 1959). Tolmie et al. (1967) first documented the interrelationship of succinylcholine-induced hyperkalaemia, electrocardiographic evidence of hyperkalaemia, and cardiovascular collapse in a patient with a severe burn.

Thomas (1969), demonstrated a significant increase in serum potassium following intravenously injected succinylcholine in a 25-year-old man with a ruptured cerebral aneurysm and subsequent paralysis. Cooperman et al. (1970) reported on a 54-year-old man after $2 \mathrm{I}$ days of left hemiparesis. The patient's potassium level was increased from 3.88 to $9.05 \mathrm{mEq}$./1. within $5 \frac{1}{2}$ minutes following the intravenous injection of succinylcholine $60 \mathrm{mg}$. The ECG showed a widened QRS complex and elevated T waves. The authors concluded that hyperkalaemia may appear in a patient who receives succinylcholine immediately after he is involved in a cerebral vascular accident or other upper-motor-neuron injury.

Stone et al. (1970) found an increase in potassium level from 4.3 to $5.6 \mathrm{mEq} . / 1$. in a 3I-year-old paraplegic man. This increase followed the intravenous administration of succinylcholine 23 days after transection of the spinal cord at the level of T8-9. A second patient developed cardiac arrest following succinylcholine infusion 46 days after spinal-cord injury at C6 with quadriplegia. His serum potassium was increased from 4.6 to i I. $6 \mathrm{mEq}$./1. in 2 minutes after succinylcholine was injected intravenously. In addition, these authors reported on the effects of succinylcholine in dogs with bilaterally sectioned sciatic nerves or transected spinal cords (Stone et al., 1970). They found that hyperkalaemia was significant beginning after the I4th day. It became highly significant at 28 days.

Tobey (1970) reports on the effects of the infusion of succinylcholine $0 \cdot I$ per cent. in four paraplegic Marines who had sustained injuries 44 to 85 days previously. In three of these patients, the serum potassium levels were increased between 7.3 and I $10 \mathrm{mEq} . / 1$. These returned to normal within Io to I 5 minutes after cessation of succinylcholine administration. In the fourth patient, the serum potassium level reached $13.6 \mathrm{mEq}$./1. within 2 minutes of the beginning of succinylcholine 0.1 per cent. infusion for a total dose of $20 \mathrm{mg}$. He developed cardiac arrest and was resuscitated successfully. The author concludes that succinylcholine should not be used in paraplegics after the first 24 to 48 hours of injury.

In a study of 40 patients with neuromuscular diseases, 15 had increases in potassium levels between I and $6 \mathrm{mEq}$. $/ \mathrm{l}$. after receiving succinylcholine, I $\mathrm{mg} . / \mathrm{kg}$. of body weight. Most increases over I mEq./1. occurred in those patients who had been ill for less than 6 months or, if they had been ill for a longer period, in those who had diseases of a progressive nature. The author concluded that the degree 
and extent of muscle paralysis seemed reciprocally related to relaxant-induced hyperkalaemia (Cooperman, I970).

Tobey et al. (I972) studied 23 patients with peripheral-nerve injuries and muscle paralysis to determine the changes in serum potassium following succinylcholine, gallamine, tubocurarine and succinylcholine preceded by $6 \mathrm{mg}$. tubocurarine. Potassium increased to $4 \mathrm{mEq}$./l. above control in venous blood of the paralysed limb, compared with only $0.7 \mathrm{mEq} . / 1$. increase in the non-paralysed limb. Neither gallamine nor tubocurarine provoked any significant change in serum potassium. Although tubocurarine prior to succinylcholine reduced the potassium responces, it did not suppress it. Smith and Grenvik (1970) and Smith (197I) reported cardiac arrest following the administration of succinylcholine in a quadriplegic patient who had been given $6 \mathrm{mg}$. tubocurarine 5 minutes earlier. Cardiovascular collapse occurred 6 months after the patient became quadriplegic.

According to well-documented reports, patients who have burns, massive trauma, and impaired neural function release a significant amount of potassium following the injection of succinylcholine. In addition, a 'vulnerable period' has been observed during which this phenomenon appears (Cooperman, 1970). Although this period of 'sensitivity' to succinylcholine in patients with neural injury is more than 6 months, the limits still have not been clearly defined (Tobey et al., 1972).

Our paraplegic patient was taken to surgery 27 days after spinal cord injury at L4. Approximately 6 minutes following the intravenous injection of succinylcholine the patient developed cardiac arrest. Unfortunately, documentation of significant hyperkalaemia and corresponding electrocardiographic changes during the cardiac arrest are not available. However, this patient possessed enough similarities to other reports to accept that this cardiovascular collapse was the result of succinylcholine-induced hyperkalaemia. Later (I 28 days post-injury), when the patient was given anaesthesia, succinylcholine was avoided. Both surgery and anaesthesia were uneventful.

\section{SUMMARY}

A cardiovascular collapse occurred in a 20-year-old white paraplegic man on the $27_{\text {th }}$ post-injury day, a few minutes after the intravenous injection of succinylcholine $75 \mathrm{mg}$. On the 128 th post-injury day, the patient underwent decompressive laminectomy of $\mathrm{L}_{3}, \mathrm{~L}_{4}$ and $\mathrm{L}_{5}$. Anaesthesia and surgery were uneventful at this time. Serum potassium and a i2-lead electrocardiographic tracings revealed no evidence of hyperkalaemia. The following drugs were used: droperidol, tubocurarine, thiopental, gallamine, nitrous oxide and fentanyl. Succinylcholine was omitted.

\section{RÉSUMÉ}

Un collapsus cardio-vasculaire a été observé quelques minutes après l'injection intraveineuse de $75 \mathrm{mg}$. de Succinylcholine chez un paraplégique de 20 ans le $27 \mathrm{èm}^{\mathrm{e}}$ jour après le traumatisme. Une laminectomie décompressive de $\mathrm{L}_{3}, \mathrm{~L}_{4}, \mathrm{~L}_{5}$ a été pratiquée le $\mathrm{I}_{2} 8 \mathrm{èm}^{\mathrm{e}}$ jour après l'accident. L'anesthésie et l'intervention chirurgicale n'ont pas été suivi, cette fois, de complications. Le dosage de la potassémie et l'électrocardiogramme n'ont révélé aucune hyperkaliémie.

Les médicaments suivants furent utilisés : Dropéridol, tubocurarine, thiopental, gallamine, protoxyde d'azote et fentanyl.

L'on oublia de donner de la Succinylcholine. 


\section{REFERENCES}

Cooperman, L. H. (I970). $\mathcal{F} A M A, \mathbf{2 1 3}, \mathrm{I} 867$.

Cooperman, L. H., Strobel, G. E. \& Kennell, E. M. (1970). Anesthesiology, 32, I6I.

Paton, W. D. M. (1959). Anesthesiology, 20, 453.

SMIth, R. B. (I97I). Canad. Anaesth. Soc. F. 18, 199.

Smith, R. B. \& Grenvik, A. (1970). Anesthesiology, 33, 558.

Stone, W. A., Beach, T. P. \& Hamelberg, W. (1970). Anesthesiology, 32, 68.

Stone, W. A., Beach, T. P. \& HamelberG, W. (1970). Anesthesiology, 32, 515.

Thomas, E. T. (1969). Anesth. Analg. 48, 333.

TOBEY, R. E. (I970). Anesthesiology, 32, 359.

Tobey, R. E., Jacobsen, P. M., KaHLe, C. T., Clubb, R. J. \& DeAN, M.A. (I972). Anesthesiology, 37, 332.

Tolmie, J. D., Joyce, T. H. \& Mitchell, G. D. (1967). Anesthesiology, 28, 467. 